\title{
A Closer Look at the Risks vs. Benefits of Kava (Piper methysticum)
}

\begin{abstract}
Anan A. Hussein ${ }^{\mathrm{a}}$
If you took a trip to Fiji, the locals would probably welcome you with a drink of Kava. For centuries, the indigenous people of the South Pacific Islands have used the roots of a plant known as Kava. Beyond the use of Kava as a psychoactive substance, it has been incorporated as a cultural drink that is used in many ceremonies. In the late 1990's Kava use spread quickly in Western countries including Europe, North America, and Australia. It was used as a treatment for anxiety. But just as quickly as it spread, the enthusiasm for it faded, because it was banned or restricted in many Western countries following reports of liver toxicity. In the United States, the Food and Drug Administration's (FDA) concern for safety prompted a request for more research on the substance. The issues of safety and efficacy remain more specifically whether the benefits of using Kava outweigh the risks.
\end{abstract}

\section{History}

Kava is a beverage made from the roots of the plant Piper methysticum, and has been used historically in the South Pacific Islands as a ceremonial drink. Kava was introduced in Europe around the 1700s by Captain James Cook and has since spread widely to Australia, Europe, and the United States. Kava is known for its psychoactive effects (sedative, anesthetic) although it is not an alcoholic substance. The Review of Natural Products states that Kava "produces mild euphoric changes, characterized by feeling of happiness,

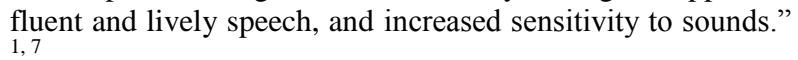

Kava is not only the traditional drink for many villages, but it is considered a significant cash crop in some islands. In Fiji, it is called yagona, and is grown and exported to Western countries for use in pharmaceuticals. Kava also accounts for a major cash yield in Tonga, Samoa, and Vanuatu. In Hawaii, Kava is used for medicinal and religious purposes. The kahunas, medical people who communicate with God used kava to cure many disease and ailments, such as chills and colds, general debility, sharp headaches, weary muscles, and displacement of the womb. 14, 15 The beverage Kava is prepared differently in each region. In Fiji and Tonga, chewing and pounding is the common method, where young boys or girls chew the plant roots without swallowing the product, then spitting the roots in a bowl. The roots are then soaked in water and the muddy water called "grog" is poured into a "bilo", a half shell of coconut and served during ceremonies. ${ }^{14,15}$

\section{Pharmacology/structure}

The chief active ingredients of Kava are kavalactones, which are concentrated in the rhizomes of the plant. There are more than 20 subspecies of Kava known but six kavalactones are responsible for more than $96 \%$ of Kava activity. Kavalactones are responsible for the psychoactive effects of kava, ${ }^{8}$ and have been found to bind sites of the brain associated with addiction and craving. A pilot study and a survey were done to determine if kavalactones decrease the craving associated with drug abuse. The substances used included alcohol, cocaine, tobacco, and heroin. The findings suggest that kava may reduce the craving associated with the aforementioned substances, which may make kava a great future candidate to help with addiction. ${ }^{13}$

Although the mechanism of action is not clear, it is believed that Kava acts on $\gamma$-aminobutyric acid-A $\left(\mathrm{GABA}_{\mathrm{A}}\right)$ binding sites, and has inhibitory effects on dopamine and norepinephrine uptake, however, studies on the activity of kava on $\mathrm{GABA}_{\mathrm{A}}$ receptors produced conflicting results. Jussofie et al. (1994) reported an increase binding of agonists and antagonists on the $\mathrm{GABA}_{\mathrm{A}}$ receptor produced by Kava extract. Alternatively, Davis et al. (1992) study concluded that Kava extract has no effect on $\mathrm{GABA}_{\mathrm{A}}$ receptors. ${ }^{16}$ Despite unknown exact mechanism of action, the majority of studies show Kava to be superior to placebo in treating anxiety. ${ }^{17} \mathrm{~A}$ review by Pittler (2000) containing seven randomized doubleblinded, placebo-controlled trials on anxiety patients using Hamilton Rating Scale for Anxiety (HAM-A) as the outcome showed reduction in anxiety among patients who received Kava extract. The subjects in the study were diagnosed based on Diagnostic and Statistical Manual of Mental Disorders (DSM-III-R). The results were not statistically significant due to the small size of participants in all of the seven studies. ${ }^{2}$ In another review by Ernst, analysis of six data sets of randomized clinical trials concluded that there is strong evidence that Kava possesses anxiolytic effects. ${ }^{9}$

\section{Pharmacokinetics}

A study on the kavalactone kawain found peak levels at 1-2 hours, with a distribution half life of 50 minutes, and an elimination half-life of nine hours. Kawain $C_{\max }$ was $2.6 \pm 0.7$ $\mu \mathrm{g} / \mathrm{ml}$, which doubled with the co-administration of Kava extract. The maximum plasma concentration $\left(T_{\max }\right)$ was $0.9 \mathrm{~h}$ which tripled to $2.5 \pm 0.9 \mathrm{~h}$ with the co-administration of Kava extract. Metabolites and kavalactones such as kawain are excreted renally mostly in urine, with some fecal excretion. ${ }^{1,10}$ 


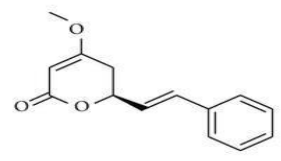

1. Kavain

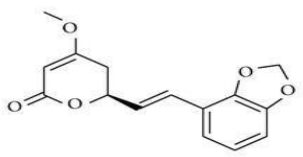

3. Methysticin

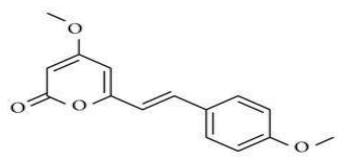

5. Yangonin

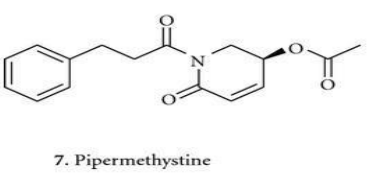

Figure 1: Major Kavalactones and their chemical structures ${ }^{4}$

Kavalactones are also potent inhibitors of Cytochrome $\mathrm{P}$ 450 (CYP 450) enzymes. An in vitro study by Mathews et al. exposed liver cells to different kavalactones from Kava extracts confirmed inhibition of CYP enzymes including CYP 2C9, 2C19, 2D6, 3A4, and 1A2. This may be a potential for many drug interactions in vivo. ${ }^{10}$

An interaction between Kava and alcohol may increase the toxicity of both kava and alcohol. In a report by Jamieson and Duffield, a combination of lipid soluble Kava and alcohol increased sleeping times in mice. A dose of $3.5 \mathrm{~g} / \mathrm{kg}$ of alcohol given with $200 \mathrm{mg} / \mathrm{kg}$ oral Kava caused hypnosis in mice, while the dose of $4.5 \mathrm{~g} / \mathrm{kg}$ of ethanol increased sleeping times significantly $(\mathrm{P}<0.001)$, and caused death in 1 of 14 treated mice. $^{8}$

Studies suggest other possible interactions with Kava including increasing the effects of benzodiazepines and anticonvulsants. ${ }^{5}$ It has also been reported that Kava reduces the effectiveness of Levodopa. Schelosky et al. reported a case in which a female with Parkinson's disease used kava twice daily and suffered from increased duration and frequency of "off periods". However, within two days of discontinuing Kava, the patient returned to her baseline disease state. $^{8,}$

\section{Safety/ Toxicology}

Since Kava is a natural product and there are multiple formulations that may vary between manufacturers, it is difficult to assess the dosage. In clinical trials, the doses most commonly used were $100 \mathrm{mg}$ (70 mg kavalactones) three times daily. ${ }^{17}$ Kava is sold in pharmacies in the U.S in doses that range anywhere from $50 \mathrm{mg}$ three times daily to $200 \mathrm{mg}$ once a day. More studies are needed to confirm the optimal dosage to maintain the safety and efficacy of Kava, and that information from the good manufacturing practice is lacking since Kava is a natural product and not an FDA approved drug. Meanwhile, the current evidence suggests 70-280 $\mathrm{mg} /$ day of kavalactones are well tolerated with an average dose of $300 \mathrm{mg} / \mathrm{day}$ in single or divided doses. Currently, there is insufficient data for safety and efficacy for Kava use in pediatrics. ${ }^{1}$

There is a widespread concern regarding hepatotoxicity with Kava use. Reports of liver damage, cirrhosis, hepatitis, and liver failure have been documented in Western countries. In Germany, the first cases of hepatotoxicity related to Kava reported 24 cases in which one was fatal. ${ }^{18}$ The median lethal dose (LD50) of some Kavalactones such as kavain, dihydrokavain, methysticin, and dihydromethysticin ranges from 41-69 intravenously, and 920-1130 orally in mice. ${ }^{1,4}$

Kavalactone Pipermethysticin (PM) is present in Kava leaves and stems and is also a potential cause of hepatotoxicity. Fischer-334 rats were given $10 \mathrm{mg} / \mathrm{kg}$ of PM daily for two weeks and demonstrated oxidative stress changes. The oxidative stress was shown to increase cytosolic superoxide dismutase enzymes and hepatic glutathione. Hepatic G2 human cells exposed to 100 micrograms PM for 24 hours showed a loss of $90 \%$ cell viability due to apoptosis.

Kavalactone Flavokavain B is a cytotoxic agent present in Kava root. Flavokavain B causes hepatocellular toxicity through mitogen-activated protein kinase (MAPK) signaling pathway which leads to oxidative stress and results in apoptosis of the cell. Flavokavain possesses more risk for hepatotoxicity due to its location in the plant roots, which makes it potentially appear in both pharmaceutical and traditional preparations of kava. ${ }^{4}$

The manufacturing process in European countries differs from the traditional preparations of Kava. In the South Pacific Islands, Kava preparations are water based, while in the Western countries ethanol and acetone are commonly used in manufacturing Kava products. In New Caledonia, Kavainduced hepatotoxicity was reported despite the use of traditional kava extracts. The issue of hepatotoxicity extending beyond Western manufacturing compels researchers to go back to the use of peeled roots of the noble Kava plant that had a safe toxicity record for hundreds of years. $^{3}$

With good evidence that Kava toxicity is not limited to the new market, proposals regarding the standardization and legislation of Kava quality were put forward. In Nov, 7 of 2002 the Kava Act of Vanuatu was passed. The Kava Act states that only noble Kava cultivars with a long history of safe traditional and medicinal use must be met before export from Vanuatu. Also, according to the Act, two day cultivars and Wichmanni (wild Kava) do not satisfy the appropriate legislation for desired kava effect and are prohibited for export. ${ }^{3,6}$

\section{Side Effects}

Considering the long history of Kava use, it is a popular product in the Pacific Islands. However, as with any substance, side effects have been reported with kava consumption. Dermatologic effects or "Kava dermopathy" have been documented among chronic users, and are characterized by dry, scaly skin with yellow pigmentation on 
the hands and feet. These effects appeared at consumption levels between $310-440$ g/week of Kava powder. ${ }^{4,18}$ Several extrapyramidal side effects resulted from short term use of Kava due to dopamine antagonism resulting in Parkinsonismlike symptoms. In other studies tachycardia and $\mathrm{P}$ wave abnormalities were reported among Kava users, particularly among young athletes. Double-blinded placebo controlled trial showed Kava ingestion has no effect on motor vehicle performance. $1,4,18$

\section{Regulation}

Kava is regulated in many countries, and the laws regarding Kava use are country specific. The sale of Kava is regulated in France and Switzerland. In Germany, all Kava containing products were withdrawn from the market in 2002. In Poland, Australia, and the United Kingdom it is illegal to sell or supply any Kava containing products, and the possession of Kava is considered a criminal offence. ${ }^{11,18}$ In the United States, Kava use is not restricted, and it is sold as an over the counter dietary supplement in most pharmacies. However, in late 2001 after receiving a total of 47 reported cases worldwide of Kava adverse events in which 20 of them were associated with liver toxicity, the FDA posted a MedWatch letter for healthcare professionals as a precautionary measure. ${ }^{18}$

\section{Kava vs. Other Agents for Treating Anxiety}

A study in Australia was done to test the effectiveness of complementary and herbal treatments for anxiety disorders. The complementary treatment was distinguished by using any self-help treatment not generally upheld in the health system. Each treatment was evaluated for its effectiveness in reducing anxiety symptoms in generalized and specific anxiety disorders (panic attacks, phobias, OCD, PTSD). Among 108 treatments used in the study, the treatments with the best evidence of effectiveness for anxiety were Kava, exercise, and relaxation training. The study included a description of evidence for at least 16 homeopathic remedies. ${ }^{19}$ Another recent review (2012), conducted a literature search for complementary medicine among other treatments for anxiety. The search revealed evidence that support Kava to be the best herbal treatment among complementary medicines that include Passion flower, Scullcap, Bacopa, Ginkgo, and St John's wort. ${ }^{20}$ Kava is beneficial for anxiety and insomnia, and does not appear to have any dependence or withdrawal effects. In clinical settings, $280 \mathrm{mg} /$ day of kavalactones were given, and follow up data of four weeks showed no effects on heart rate, blood pressure, or sexual dysfunction. No differences between Kava and placebo were found. ${ }^{12}$ The best current pharmacological therapies used for anxiety disorders include benzodiazepines and antidepressants. Limitations to these agents include dependence, withdrawal side effects, and the potential for drug abuse. This could make the approach towards Kava use for anxiety more beneficial.

\section{Conclusion}

Kava showed superior efficacy compared with other CAM products in treatment of anxiety. Kava is well tolerable, and does not lead to dependence unlike benzodiazepines.
Unfortunately, the liver toxicity reports associated with its use have resulted in decreased use in the West despite its effectiveness. It is known that Kava should not be used in high doses or frequency, and it should not be mixed with alcohol. Patients with history of hepatic impairment of any kind should also avoid Kava. There is a need for more safety and efficacy data on Kava. Perhaps a good future study can focus on isolating kavalactones, and avoid the manufacturing of the kavalactones identified as potentially hepatotoxic. Considering the positive effects of Kava, and the lack of complete knowledge about the liver toxicity associated with it, it should be used with caution until future studies assess its safety.

\section{Acknowledgments}

An earlier version of this review was originally completed as a course project for RX 462 Drug Abuse and Society at Husson University.

We would like to thank Dr. Alla Fabrikant, Assistant professor of pharmacy practice at Husson University, and Jessica Bates, PharmD candidate at Husson University for their support and suggestions, and their assistance in editing this article.

\section{References}

1. Basch E, Basch S, Bent C, et al. Kava (Piper methysticum). Natural Standard. http://husson.naturalstandard.com.husson.idm.oclc.org/d atabases/herbssupplements/kava.aspUpdated 4.8.2014. Accessed Mar 15, 2014.

2. Abadi S, Papoushek C, Evans M. Is kava extract effective for treating anxiety? Can Fam Physician. 2001; 47:1745-7. http://www-ncbi-nlm-nihgov.husson.idm.oclc.org/pmc/articles/PMC2018572/pdf/ 11570299.pdf Published Sep, 2001. Accessed Mar 15, 2014

3. Teschke R, Sarris J, Glass X, Schulze J. Kava, the anxiolytic herb: Back to basics to prevent liver injury? Br J Clin Pharmacol. 2011; 71(3): 445-448. doi: $10.1111 / \mathrm{j} .1365-2125.2010 .03775 . x$.

4. Rowe A, Zhang L, Ramzan I. Toxicokinetics of Kava. Adv Pharmacol Sci. 2011; 2011: 326724. doi: 10.1155/2011/326724.

5. Ehrlich SD. Kava Kava. University of Maryland Medical Center. http://umm.edu/health/medical/altmed/herb/kava-kava Updated: May 7, 2013. Accessed Mar 28, 2014.

6. Teschke R. Kava and the risk of liver toxicity: Past, current, and future. AHPA. 2011;26:12. http://www.ahpa.org/portals/0/pdfs/11_0303_March2011 _AHPA_Report_Kava_Special_Report.pdf Published Mar, 2011. Accessed Apr 6, 2014.

7. Pepping J. Kava: Piper methysticum. Am J Health Syst Pharm. 1999 May 15; 56(10):957-8, 960. file://C:/Users/Anan/Downloads/36023842\%20(3).pdf Published 1999. Accessed Apr 15, 2014.

8. Ankea J, Ramzana I. Pharmacokinetic and pharmacodynamic drug interactions with Kava (Piper methysticum Forst. f). J Ethnopharmacol. 2004 Aug; 93(2-3):153-60. doi:10.1016/j.jep.2004.04.009. 
9. Ernst E. Herbal remedies for anxiety - a systematic review of controlled clinical trials. Phytomedicine. 2006; 13(3):205-8. http://www.ncbi.nlm.nih.gov/pubmed/16428031?dopt=A bstract Pub Aug 15, 2005. Accessed Apr, 2014.

10. Mathews J, Etheridge A, Valentine J. Pharmacokinetics and disposition of the Kavalactone Kawain: Interaction with Kava extract and Kavalactones in vivo and in vitro. Drug Metab Dispos. 2005 . 33 (10): 1555-1563. doi:10.1124/dmd.105.004317.

11. Makaira. Kava-Worldwide Legal Status. Kona Kava Farm. http://www.konakavafarm.com/blog/kavanews/kava-worldwide-legal-status/ . Posted Jul 24, 2009. Accessed Apr, 2014.

12. Connor KM, Davidson JR, Churchill LE. Adverse-effect profile of Kava. CNS Spectr $2001: 6(10): 848,850-3$. http://www.ncbi.nlm.nih.gov/pubmed/15334034. Accessed Apr, 2014.

13. Steiner G. Kava as an anticraving agent: preliminary data. Pac Health Dialog. 2001; 8(2): 335-9. http://www.ncbi.nlm.nih.gov/pubmed/12180513?report= abstract. Accessed Apr, 2014

14. Davis R.I, Brown J.F. Kava (Piper methysticum) in the South Pacific: its importance, methods of cultivation, cultivars, diseases and pests. Australian Centre for International Agricultural Research. 1999; 46, 32. http://ageconsearch.umn.edu/bitstream/113917/2/tr046_p df_19769.pdf. Published 1999. Accessed Apr 20, 2014.

15. Singh Y. Kava: an overview. J Ethnopharmacol. 1992; 37(1):13-45. file:///C:/Users/Anan/Downloads/36023308\%20(1).pdf. Published 1992. Accessed Apr 20, 2014.

16. Garret M. Basmadjian G. Khan I. et al. Extracts of kava (Piper methysticum) induce acute anxiolytic-like behavioral changes in mice. Psychopharmacology (Berl). 2003;170(1):33-41. DOI 10.1007/s00213-0031520-0

17. Kava. Natural medicines. http://naturaldatabase.therapeuticresearch.com.husson.id m.oclc.org/nd/Search.aspx?cs=CEPDA\&s=ND\&pt=100 $\underline{\text { \&id }=872 \& d s=\text { dosage }}$. Last Updated Nov 4, 2014. Accessed Nov 4, 2014.

18. Coulter D. Assessment of the risk of hepatotoxicity with kava products. World Health Organization. 2007. http://books.google.com/books?hl=en\&lr=\&id=2KXWY 6kPESUC\&oi=fnd\&pg $=$ PR1\&dq $=$ assessment + of + the + ri sk+of+hepatotoxicity+with+kava+products\&ots $=\mathrm{Ne}-$ tA7Et94\&sig=tQbbt4B24jTTJROR8210mpDGESk\#v=o nepage \&q=assessment $\% 20$ of $\% 20$ the $\% 20$ risk $\% 20$ of $\% 20$ hepatotoxicity $\% 20$ with $\% 20$ kava $\% 20$ products $\& \mathrm{f}=$ false. Accessed Nov 1, 2014.

19. Jorm A, Christensen H, Griffins K, et al. Effectiveness of complementary and self-help treatments for anxiety disorders. Med J Aust. 2004; 181(7): 29.

https://www.mja.com.au/journal/2004/181/7/effectivenes s-complementary-and-self-help-treatments-anxietydisorders. Accessed Nov 4, 2014.

20. Sarris J, Moylan S, Camfield D, et al. Complementary medicine, exercise, meditation, diet, and lifestyle modification for anxiety disorders: A review of current evidence. Evid Based Complement Alternat Med. 2012; 2012: 809653. Doi: 10.1155/2012/809653 